\title{
Canadian Institute of Forestry / Institut Forestier du Canada Incorporation, Objects \& By-laws • Incorporarion, buts et règlements
}

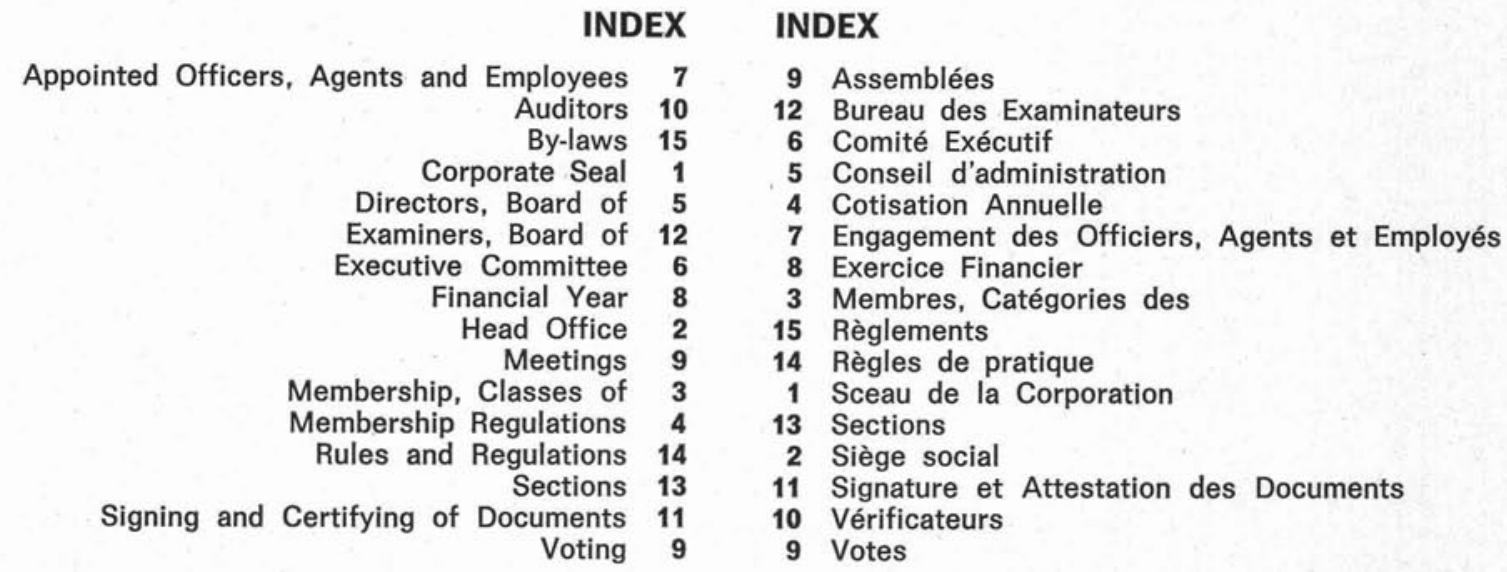

INCORPORATION AND OBJECTS

Under the provisions of Part II of the Canadian Corporations Act, 1965, under Letters Patent of September 1950 and under Supplementary Letters Patent of December, 1965 , the Institute is incorporated as a corporation without share capital and with the name of CANADIAN INSTITUTE OF FORESTRY - INSTITUT FORESTIER DU CANADA for the purpose of carrying on in more than one Province of Canada, without pecuniary gain to its members, the following objects:

a/ To encourage a wider understanding of the problems of forestry including the maintenance and improvement of the environment.

b/ To improve all aspects of forestry practice in Canada.

c/ To advance the members in their knowledge of the science and in the practice of forestry.

d/ To cultivate an esprit de corps within the profession.

e) To publish The Forestry Chronicle in the interests of forestry.

(Forestry: The science, the art and the practice of managing and using for human benefit the natural resources that occur on and in association with forest lands. As defined in Termino logy of Forest Science, Technology, Practice and Products, the Society of American Foresters.

BY-LAWS

These By-laws are as adopted at the Annual General Meeting of the Institute in October 1975 and approved subsequently by the Corporation Branch, Department of Consumer and Corporate Affairs.

\section{1}

CORPORATE SEAL

The seal of the Institute shall be in such form as has been prescribed by the Directors of the Institute and shall be endorsed with the words Canadian Institute of Forestry - Institut Forestier du Canada.

\section{2}

HEAD OFFICE

The head office of the Institute shall be located at Macdonald College, Ste. Anne de Bellevue, in the Province of Quebec, or such other place as the Board of Directors may determine.

\section{INCORPORATION ET BUTS}

En vertu des dispositions de la deuxième Partie de la Loi sur les corporations canadiennes, 1965 et en vertu des Lettres Patentes émises en septembre 1950 ainsi que des Lettres Patentes supplémentaires émises en décembre 1965 . I'Institut est incorporé comme corporation sans capitalactions sous le nom CANADIAN INSTITUTE OF FORESTRY - INSTITUT FORESTIER DU CANADA ayant pour but de réaliser, dans plus qu'une province du Canada, sans but lucratif pour ses membres, les fins suivantes:

a/ Favoriser une meilleure compréhension des problèmes de foresterie, y compris le maintien et l'amélioration du milieu.

b/ Améliorer tous les aspects de la pratique de la foresterie au Canada.

c/ Perfectionner la connaissance de la science et de la pratique de la foresterie chez ses membres.

d/ Cultiver un esprit de corps dans les rangs de la profession.

e/ Publier The Forestry Chronicle pour le bien de la foresterie.

(Foresterie: La science, l'art et la pratique de la gestion et de I'utilisation au profit de l'homme des ressources naturelles que I'on trouve sur les terrains à vocation forestière. Terminology of Forest Science, Technology, Practice and Products, The Society of American Foresters. Traduction de I'I.F.C.)

\section{RÈGLEMENTS}

Les Règlements en vigueur sont tels qu'adoptés par l'assemblée générale annuelle de I'Institut tenue en octobre 1971 et approuvés subséquemment par le Bureau des Corporations du Ministère de la Consommation et des Corporations.

\section{LE SCEAU DE LA CORPORATION}

Le sceau de l'Institut doit avoir la forme qui a été ordonnée par les administrateurs de I'Institut; ce sceau doit être accompagné de l'inscription suivante: Canadian Institute of Forestry - Institut Forestier du Canada.

\section{SIÈGE SOCIAL}

Le siège social de l'Institut sera situé au Collège Macdonald, Ste-Anne-de-Bellevue, Province de Québec, ou dans toute autre localité choisie par le Conseil d'administration. 
3.1.1 Fellow qualification. A member who has made outstanding contributions to the advancement of forestry may be elected a Fellow of the Institute by not fewer than two-thirds of the votes cast at a meeting of the Board of Directors.

3.1.2 Fellow privileges. Fellows of the Institute shall be exempt from payment of membership dues and shall enjoy the rights and privileges accorded to Active Members.

3.1.3 Honorary qualification. A non-member who has made outstanding contributions to the advancement of forestry may be elected an Honorary Member by not fewer than two-thirds of the votes cast at a meeting of the Board of Directors.

3.1.4 Honorary privileges. Honorary Members shall be exempt from payment of membership dues and shall enjoy the rights and privileges accorded to Active Members.

\section{Active Members}

The following three classes of individuals are eligible for Active membership and shall be admitted upon acceptance by a Section Council or the Executive Committee.

3.2.1 Forestry graduates. Persons who have received a graduate or post-graduate degree in forestry, forest engineering or applied science in forestry from a college or university recognized by the Board of Directors as providing courses of satisfactory standing.

3.2.2 Allied-science graduates engaged in forestry. Persons who are not eligible under Sub-section 3.2.1 but who have received a graduate or post-graduate degree in an allied science from a college or university recognized by the Board of Directors as providing courses of satisfactory standing, and who have been engaged for at least five years in some branch of forestry.

3.2.3 Provincial registration. Persons who are members of a provincial registered foresters association.

The following two classes of individuals are eligible for Active membership and shall be admitted upon the recommendations and approvals specifically noted for each class.

3.2.4 Affiliate members in responsible forestry positions. Affiliate members holding responsible forestry positions who have been sponsored by two Active members, recommended by a Section Council and approved by the Board of Examiners.

3.2.5 Special qualification. Persons in positions of professional responsibility who have special qualifications and long and valuable experience in forest activities and who have been recommended by a Section Council, the Board of Examiners and the Board of Directors.

3.3 Affiliate Members

Examination of qualifications. The Section Council concerned shall examine the qualifications of an applicant for Affiliate membership and shall authorize acceptance by the Institute if appropriate. In cases of doubt as to the qualifications of such applicants the Executive Committee shall make the final decision based upon a report from the Board of Examiners.

The following are eligible for Affiliate Membership:
Qualifications des membres émérites. Tout membre qui a contribué de façon particulièrement remarquable à l'avancement de la foresterie peut être élu membre émérite de I'Institut par un minimum de deux-tiers des voix, lors d'une réunion du Conseil d'Administration.

Privilèges attachés au titre de membre émérite. Les membres émérites de l'Institut ne sont tenus de payer aucun droit d'adhésion et jouissent des mêmes droits et privilèges que les membres actifs.

Qualifications des membres honoraires. Toute personne, ne faisant pas partie de l'Institut, qui a contribué de façon particulièrement remarquable à l'avancement de la Foresterie, peut être élue membre honoraire par un minimum de deux-tiers des voix à une réunion du Conseil d'Administration.

Privilèges attachés au titre de membre honoraire. Les membres honoraires sont exemptés des frais d'adhésion et jouissent des mêmes droits et privilèges que les membres actifs.

\section{Membres Actifs}

Les personnes faisant partie d'une des trois classes décrites ci-après sont admissibles comme membres actifs et seront admises sur le consentement du Conseil d'une Section ou du Comité exécutif.

Bacheliers en foresterie. Toutes personnes détenant un baccalauréat ou un diplôme d'études postscolaires en foresterie, en génie forestier ou en science appliquée (foresterie). d'un collège ou d'une université dont le programme d'études est approuvé par le Conseil d'administration.

Diplômés en science appliquée pratiquant la foresterie. Toutes personnes qui ne sont pas éligibles sous la section 3.2.1 mais qui détiennent un diplôme de baccalauréat ou d'études post-graduées dans une science connexe, d'un collège ou université dont le programme d'études est approuvé par le Conseil d'administration et qui travaillent depuis au moins cinq ans dans une branche de la foresterie.

Association provinciale. Toutes personnes qui sont membres d'une association provinciale de forestiers professionnels reconnue.

Les personnes des deux catégories décrites ci-après sont admissibles comme membres actifs et seront admises sur recommandation et approbation telles que notées spécifiquement dans chaque cas.

Membres affiliés occupant un poste de commande en foresterie. Les membres affiliés occupant un poste de commande en foresterie dont la demande d'admission est parrainée par deux membres actifs, recommandée par le Conseil d'une Section et approuvée par le Conseil d'administration.

Titre d'éligibilité spéciale. Toutes personnes occupant un poste d'une responsabilité professionnelle qui ont un titre d'éligibilité spéciale venant d'une longue expérience de grande valeur dans les activités forestières et qui ont été recommandées par un Conseil de Section, par le Bureau des Examinateurs et le Conseil d'administration.

\section{Membres Affiliés}

Vérification des titres d'éligibilité. Le Consell de Section en cause doit examiner les titres d'éligibilité de tous candidats au titre de membres affillés et en autoriser l'admission par l'Institut s'il les juge adéquats. En cas de doute quant à la valeur des titres d'éligibilité de ces candidats, le Comité exécutif devra prendre la décision finale suite à un rapport du Bureau des Examinateurs. 
3.3.1 Non-graduates engaged in forestry. Persons who, while not degree graduates of a college or university, have been engaged for at least five years in some branch of forestry, or who have received a diploma or certificate in forestry engineering from a technical school.

3.3.2 Non-graduates of value to forestry. Persons who, while not degree graduates of a college or university, have, in the opinion of a Section Council, indicated interest in forestry and who are considered to be in a position to contribute to the advancement of forestry principles.

\subsection{Student Members}

The following are eligible for Student Membership:

3.4.1 Undergraduates or post-graduates in forestry. Persons who are registered as undergraduates or post-graduates and who are proceeding to a degree in forestry or forest engineering.

3.4.2 Forestry graduates in full-time study. Persons who have received a degree in forestry or forest engineering, or who are already members of the Institute, and who are registered as students on a full-time basis.

3.4.3 Technical school students. Persons who are registered as students in a technical school who are proceeding to a diploma or certificate in forestry or forestry engineering. REGULATIONS

4.1 Dues

4.1.1 Amount and conditions of payment. The scale of membership dues and the conditions of payment may be recommended by the Board of Directors and must be ratified by vote at an annual general meeting or at any special general meeting called for the purpose, inter alia, of considering the matter.

\subsubsection{Date due and non-payment.}

4.1.2.1 Dues are due and payable on the first day of July each year.

4.1.2.2 If the dues of an Active or Affiliate Member have not been paid on or before the first day of October of the current year, or in the case of a Student Member on or before the last day of December of the current year, then such a delinquent member shall be struck off the rolls and notified accordingly by registered mail to the last known address.

4.1.3 Reinstatement. Formal application for reinstatement of a member struck off the rolls for nonpayment of dues shall be considered for acceptance if accompanied by payment of dues for the current year plus a reinstatement charge which may be established from time to time by the Executive Committee.

\subsection{Resignation}

4.2.1 Any member may withdraw from the Institute by submitting a letter of resignation to the SecretaryManager.

\subsection{Expulsion}

4.3.1 Any member may be required to withdraw from the Institute by a vote of three-quarters of the members of the Board of Directors.
Personnes non-diplômées travaillant en foresterie. Toute personne qui, bien que n'ayant pas obtenu de diplôme collégial ou universitaire, travaille depuis cinq ans au moins dans une branche quelconque de la foresterie, ou toute personne qui a obtenu un diplôme ou certificat en foresterie ou en génie forestier dans un collège technique.

Personnes sans degré universitaire travaillant en dehors de la foresterie. Toutes personnes qui, quoique ne détenant pas un baccalauréat d'un collège ou d'une université, ont, dans I'opinion d'un Conseil de Section montré de l'intérêt pour la foresterie et qui sont considérées comme occupant une position où elles peuvent contribuer à l'avancement des principes de la foresterie.

\section{Membres Etudiants}

Les personnes suivantes sont admissibles comme membres étudiants:

Etudiants universitaires en foresterie. Toutes personnes inscrites à une université pour études en vue d'un baccalauréat en foresterie ou en génie forestier.

Diplômés en foresterie inscrits comme étudiants réguliers. Toutes personnes qui détiennent un diplôme en foresterie ou en génie forestier ou qui sont déjà membres de l'Institut et qui se sont inscrites comme étudiants réguliers.

Etudiants d'un Collège Technique. Tout étudiant inscrit dans un Collège Technique en vue d'obtenir un diplôme ou certificat en foresterie ou en génie forestier.

\section{RÉGLEMENTATION CONCERNANT LA COTISATION ANNUELLE}

\section{Cotisation Annuelle}

Montant et modalités de paiement. Le barème de la cotisation annuelle des membres et les modalités de paiement peuvent être établis par le Conseil d'administration, mais par la suite doivent être ratifiés lors de l'assemblée générale annuelle ou à l'occasion d'une assemblée générale extraordinaire convoquée pour discuter de ce point en particulier et de tout autre sujet.

\section{Echéance et défaut de paiement}

La cotisation annuelle est échue et payable chaque année le premier jour de juillet.

Si un membre actif ou affilié n'a pas versé sa cotisation le ou avant le premier jour d'octobre de l'année en cours, ou s'il s'agit d'un membre ayant le statut d'étudiant le ou avant le premier jour de décembre de la même année, alors ce membre, pris en défaut sera biffé du registre des membres et avisé en conséquence par courrier recommandé à sa dernière adresse connue.

Réinscription. Une demande officielle de réinscription d'un membre rayé du registre de l'Institut à cause d'un manquement à payer sa cotisation annuelle ne sera considérée que si, à cette demande officielle, le membre joint le paiement de sa cotisation annuelle pour l'année en cours, en plus d'un droit de réinscription tel qu'établi de temps en temps par le Comité exécutif.

\section{Démission}

Tout membre peut se retirer de l'Institut en faisant parvenir au Secrétaire administratif une lettre de démission.

\section{Expulsion}

Tout membre peut être expulsé de I'Institut à la suite d'un vote des trois-quarts des membres du Conseil d'administration.

Retraite 
4.4.1 Application for retired status. An Active or Affiliate Member who has been a member of the Institute for fifteen or more years and who retires from such activity as was the basis of his qualification for membership, may apply to his Section Council for a continuation in that class of membership without payment of dues. 'Retirement' shall be interpreted as retirement from full-time employment with a substantial reduction in income.

4.4.2 Examination. The Section Council shall examine an application for Retired status and may recommend acceptance by the Executive Committee. Under special circumstances the mintmum requirement of fifteen years previous membership may be waived if Council so advises.

4.4.3 Subscription to The Forestry Chronicle. Retired members may receive The Forestry Chronicle on payment of such annual charge as may from time to time be recommended by the Board of Directors for approval by the membership.

4.5 Applicants without Section Affiliation

4.5.1 Applications for Active, Affiliate, Student and Retired membership from applicants who are not affiliated with a Section should be forwarded to the Secretary-Manager for consideration by the Executive Committee.

\section{BOARD OF DIRECTORS}

\subsection{Composition}

5.1.1 The Board of Directors shall consist of one representative from each Section together with the members of the Executive Committee. All Directors must be Active Members of the Institute.

5.2 Appointment of Section Representatives and Alternates

5.2.1 Method of appointment. After the annual general meeting of the Institute, and before the first day of July following, each Section shall elect or appoint their representative who will assume the duties of Director. Election may be either by letter ballot or at a Section general meeting or, if the

Section By-laws permit, by appointment by the Section Council. In like manner each Section shall elect an Alternate who shall act in the place of, and enjoy all the rights and privileges of the Director only in the latter's unavoidable absence or in the circumstances governed by By-law 5.3. Within one month of the election of a Director and his Alternate, the Secretary of the Section concerned shall notify the Secretary-Manager of the result of the election.

5.5.2 Term of office. A Director representing a Section shall assume office on the first day of July following his election, and shall hold office until the thirtieth day of June following. He may be reelected for subsequent terms.

5.2.3 Avoidance of duplication. A member may not act as a Section Representative on the Board of Directors and as an elected Officer of the Institute concurrently. An appointment as Section representative (or alternate) on the Board is void when the incumbent assumes office as a member of the Executive Committee. In such an event the Section concerned shall elect or appoint to the Board another representative or other alternate. This election or appointment shall take place at least thirty days before the next ensuing annual general meeting, or according to By-law 5.2.1,
Demande pour se prévaloir du statut de retraité. Un membre actif ou affilié qui a fait partie de I'Institut pendant quinze ans ou plus et qui prend sa retraite d'un travail qui le rendait éligible à cette catégorie de I'Institut peut faire, au Conseil de sa Section, une demande pour que soit continuée dans cette catégorie, son appartenance à l'Institut sans cotisation annuelle. II est bien entendu que le mot retraité doit être interprété comme signifiant l'abandon complet d'une position à plein temps avec une réduction substantielle de revenu.

Examen de la demande du statut de retraité. Le Conseil de Section vérifiera la demande d'un membre au statut de retraité et recommandera ou non l'acceptation de cette demande au Comité exécutif. Dans des cas particuliers. si bien entendu le Conseil de Section l'approuve, on pourra faire exception à l'obligation d'avoir été membre de I'Institut pendant une période minimale de quinze ans.

Abonnement au The Forestry Chronicle. Les membres retraités peuvent recevoir la revue The Forestry. Chronicle moyennant le paiement d'une somme annuelle fixée par le Conseil d'administration et approuvée par les membres de I'Institut.

\section{Demande d'Admission sans faire partie d'une Section}

Les demandes d'admission pour devenir soit membre actif, affilié, étudiant ou membre à la retraite, qui ne sont pas faites par le truchement d'une Section, dervont être transmises au Secrétaire administratif qui les soumettra pour fins d'examen au Comité exécutif.

\section{CONSEIL D'ADMINISTRATION}

\section{Composition}

Le Conseil d'administration sera composé d'un représentant de chaque section ainsi que des membres du Comité exécutif. Tous les administrateurs devront être membres actifs de I'Institut.

\section{Nomination des Représentants des Sections et des Substituts}

Mode de nomination. Après l'assemblée générale annuelle de I'Institut, et avant le premier jour de juillet qui suit, chaque Section devra choisir ou nommer son représentant au Conseil d'administration. L'élection pourra se faire soit par bulletin de vote, à une assemblée générale de la Section ou, si les règlements de la Section le permettent, par désignation par le Conseil de la Section. De la même façon chaque Section devra élire un substitut qui remplacera l'administrateur, et jouira des mêmes droits et privilèges, mais seulement si l'absence de ce dernier est inévitable ou dans les circonstances prévues au règlement 5.3. Dans un délai d'un mois après l'élection de l'administrateur et de son substitut, le secrétaire de la Section concernée devra aviser le Secrétaire administratif du résultat de l'élection.

Durée de la fonction. Un administrateur représentant une Section devra entrer en fonction le premier jour de juillet suivant son élection, et devra demeurer en fonction jusqu'au trentième jour du mois de juin suivant. II pourra être réélu pour des termes subséquents.

Duplication à éviter. Un membre ne peut agir en même temps comme représentant d'une Section au Conseil d'administration et en tant qu'officier élu de I'Institut. Une nomination à titre de représentant (ou substitut) d'une Section au Conseil devient nulle au moment où cette même personne entre en fonction comme membre du Comité exécutif. Dans un tel cas la Section concernée élira ou nommera un autre représentant ou un substitut au Conseil. Cette élection ou nomination aura lieu au moins trente jours avant la tenue de l'assemblée générale annuelle subséquente ou d'après le règlement 5.2 .1 , selon la première éventualité, et pourra s'effectuer suivant une décision de 
whichever comes first, and may be by resolution either of a Section general meeting or, if this is not feasible, of the Section Council.

\section{Resignation and Removal}

A Directorship may become vacant if the incumbent:

5.3.1 Resigns in writing to the Chairman of his Section.

5.3.2 Does not remain an Active Member.

5.3.3 Is unable to carry on his duties as Director due to ill health or financial difficulties.

5.3.4 Has assumed office as a member of the Executive Committee.

\section{$5.4 \quad$ Meetings}

5.4.1 Calling of meetings. Meetings of the Board of Directors may be held at any time and place as determined by the Directors, or at the call of the President, providing that fourteen days notice of such meeting shall be sent in writing to each Director. No formal notice shall be necessary if all Directors are present at the meeting or sign written waivers of such notice.

5.4.2 Quorum. A quorum of the Board of Directors is a quorum of the Executive Committee (By-law 6.9.2) plus $50 \%$ of the Section Representatives on the Board.

5.4.3 Decisions. Decisions of the Board shall be made by a simple majority of the votes cast, except when provisions to the contrary are stated elsewhere in these By-laws. In the event of a tied vote the President's decision shall be binding.

\section{Remuneration and Expenses}

Directors, as such, shall not receive any remuneration for their services except as may be prescribed by resolution of the members of the Institute. The Board may resolve for the Institute to reimburse all or any part of the expenses of Directors incurred by their attendance at any meeting of the Board. Nothing herein contained shall be construed so as to preclude any Director from serving the Institute and receiving compensation as an appointed officer or in any other appointed capacity.

\subsection{Powers and Responsibilities}

5.6.1 The Board of Directors shall manage the property and business of the Institute and may exercise all such powers of the Institute as are not required by the Corporations Act or by these By-laws to be exercised by the Active Members at general meetings or special general meetings. Within the same limitations the Board may delegate its powers to the Executive Committee as provided by By-law 6.8.

5.6.2 The Board of Directors may authorize investments and expenditures on behalf of the Institute, and may from time to time borrow upon the credit of the Institute such moneys and in such manner as they see fit.

5.6.3 The Board of Directors may from time to time as they see fit grant securities by way of mortgage, hypothecation or pledge covering all or any of the assets of the Institute as security for all or any other liability of the Institute.

\section{EXECUTIVE COMMITTEE}

\section{Composition}

The members of the Executive Committee shall be: the President, the Past President, the First VicePresident, and the Second Vice-President. l'assemblée générale de la Section, ou si ce n'est pas possible, du Conseil de la Section.

\section{Démission et Déplacement}

Un siège au Conseil d'administration peut devenir vacant si le titulaire:

Remet sa démission par écrit au Président de sa Section. $\mathrm{Ne}$ demeure pas membre actif.

$\mathrm{Ne}$ peut pas accomplir ses devoirs d'administrateur pour cause de santé ou de difficultés financières.

S'il devient membre du Comité exécutif.

\section{Réunions}

Demande des réunions. Les réunions du Conseil d'administration peuvent être tenues à toute date et endroit désignés par les administrateurs, ou à la demande du Président, à la condition qu'un avis écrit ait été envoyé à chaque administrateur quatorze jours avant la réunion. Un avis officiel ne sera pas nécessaire si tous les administrateurs sont présents à la réunion ou s'ils renoncent par écrit à recevoir un tel avis.

Quorum. Le quorum du Conseil d'administration est le quorum du Comité exécutif (règlement 6.9 .2 ) plus $50 \%$ des représentants de section au Conseil.

Décisions. Les décisions du Conseil seront adoptées par la majorité absolue des votes enregistrés, à moins que des mesures contraires soient prévues ailleurs dans ces règlements. En cas d'égalité, le Président aura un vote prépondérant.

\section{Rémunération et Dépenses}

Les administrateurs, comme tels, ne recevront aucune rémunération pour leurs services sauf ce qui pourra être établi par résolution des membres de l'Institut. Le Conseil peut décider au nom de l'Institut de rembourser en tout ou en partie les dépenses des administrateurs encourues pour assister à toute réunion du Conseil. Rien de ce qui précède ne doit être interprété comme devant empêcher un administrateur de bien servir l'Institut et de recevoir une compensation à titre d'officier attitré ou pour toute autre fonction qui lui aurait été assignée.

\section{Pouvoirs et Responsabilités}

Le Conseil d'administration devra administrer les biens et les affaires de l'Institut et pourra exercer tous les pouvoirs de I'Institut que la Loi sur les corporations canadiennes ou les présents règlements ne réservent pas aux membres actifs en assemblées générales extraordinaires. Dans les cadres de ces restrictions, le Conseil peut transmettre ses pouvoirs au Comité exécutif tel que prévu au règlement 6.8.

Le Conseil d'administration peut autoriser des placements et des dépenses au nom de l'Institut et peut de temps à autre emprunter les sommes d'argent requises suivant le pouvoir d'emprunt de l'Institut et de la façon qu'il le juge à propos.

Le Conseil d'administration peut de temps à autre, selon qu'il le juge à propos, déposer des titres en nantissement, sur hypothèque ou en garantie couvrant tous ou n'importe quel des biens de l'Institut, en gage de toutes les dettes de l'Institut ou partie d'icelles.

\section{COMITÉ EXÉCUTIF}

\section{Composition}

Le Comité exécutif se composera des membres suivants: le Président, le Président sortant, le premier Vice-Président, et le second Vice-Président. 
The members of the Executive Committee shall be ex-officio Directors of the Institute.

\section{Past President}

The Past President shall be that member who has most recently completed a term of office as President.

\subsection{President}

6.4.1 Assumption of office. The First Vice-President shall automatically become President at the end of the second annual general meeting following his election as First Vice-President.

6.4.2 Replacement. If the office of President falls vacant for any reason, the vacancy shall automatically be filled by the First Vice-President who shall continue as President for the remainder of his predecessor's term and for his own term of office at his discretion. If there is no First Vice-President to succeed to the Presidency, then the Second Vice-President shall become Acting President until a new First Vice-President is elected.

\section{$6.5 \quad$ Vice-Presidents}

6.5.1 Normal and exceptional circumstances. The First Vice-President and the Second Vice-President normally shall be elected annually by ballot vote of the members as provided for under this By-law, but in exceptional circumstances the Board of Directors may direct an election at the annual, or a special, general meeting, or by a letter ballot.

\subsubsection{Election procedure}

6.5.2.1 Nominating committee. Each year between the conclusion of the annual general meeting and December 31 next following, the President shall appoint a Nominating Committee of at least three Active Members of the Institute and shall ensure that the Chairman and Secretary of each Section are advised of the composition of the Committee and the mailing address of its Chairman.

6.5.2.2 Nominations. Nominations must be delivered to the Chairman of the Nominating Committee before March 31. Candidacies may be initiated in the following ways:

6.5.2.2.1 By a letter endorsed by six voting members.

6.5.2.2.2 By a letter, certifying a majority vote of a Section at a duly constituted general meeting, signed by the Chairman and the Secretary.

6.5.2.2.3 By the Nominating Committee in its own right.

6.5.2.3 Examination. The Nominating Committee shall examine each nomination and shall accept those which are in order.

6.5.2.4 Delivery. The Nominating Committee shall, not later than April 30 following its appointment, deliver to the Secretary-Manager at least one nomination for each of the offices of First Vice-President and Second Vice-President, and every such nomination shall be accompanied by the written consent of the nominee that he will act if elected.

\subsubsection{Ballot.}

6.5.2.5.1 The Secretary-Manager shall prepare a ballot containing all valid nominations. The ballot shall be mailed to all voting members on or before May 15. The ballots shall be returnable to the head office not later than June 30 , of the same year.

6.5.2.5.2 On or before June 30 of the same year, the President shall appoint two scrutineers to assist the Secretary-Manager in tabulating the results of the ballot.

\section{Statut comme Administrateurs}

Les membres du Comité exécutif seront d'office Administrateurs de I'Institut.

\section{Le Président sortant}

Le Président sortant est le membre qui a terminé le plus récemment un terme à la présidence.

\section{Président}

Entrée en fonction. Le premier Vice-Président assumera automatiquement les fonctions de Président au terme de la seconde assemblée générale annuelle suivant son élection comme second Vice-Président.

Substitution du Président. Si le poste de Président devient vacant pour une raison quelconque, le premier Vice-Président assumera automatiquement cette fonction pour le reste du terme de son prédécesseur et également pour son propre terme comme bon lui semblera. S'il n'y a pas de premier Vice-Président pour succéder à la présidence, alors le second Vice-Président assumera temporairement le poste de Président jusqu'à l'élection d'un nouveau premier Vice-Président.

\section{Vice-Présidents}

Situations normales et exceptionnelles. Le premier VicePrésident et le second Vice-Président seront élus annuellement par voie de scrutin par les membres, tel que défini au présent règlement, mais dans des circonstances exceptionnelles le Conseil d'administration peut tenir une élection à une assemblée générale annuelle ou extraordinaire ou par voie de scrutin.

\section{Procédure d'élection}

Comité de nomination. Chaque année après l'assemblée générale annuelle et avant le 31 décembre suivant, le Président constituera un Comité de nomination comprenant au moins trois membres actifs de l'Institut et s'assurera que le Président et le Secrétaire de chaque Section sont avisés de la formation du comité et de l'adresse postale de son Président.

Nominations. Les nominations devront parvenir au Président du Comité de nomination avant le 31 mars. Les candidatures peuvent être soumises comme suit:

Par lettre signée par six (6) membres actifs.

Par lettre signée par le Président et le Secrétaire d'une Section certifiant qu'il y a eu scrutin majoritaire lors d'une assemblée dûment convoquée de la Section.

Par le Comité de nomination usant de ses prérogatives.

Examen. Le Comité de nomination devra vérifier chaque nomination et accepter celles qui sont dans l'ordre.

Rapport. Le Comité de nomination devra, au plus tard le 30 avril suivant sa convocation, remettre au Secrétaire administratif le nom d'au moins un candidat pour les postes de premier Vice-Président et de second Vice-Président, et chaque candidature devra être accompagnée d'une lettre signée par le candidat affirmant qu'il acceptera le poste advenant son élection.

Bulletin de vote.

Le Secrétaire administratif préparera un bulletin de vote contenant toutes les nominations validées. Le bulletin de vote sera posté à tous les membres ayant droit de vote le ou avant le 15 mai. Les bulletins de vote doivent être retournés au siège social avant le 30 juin de la même année.

Le ou avant le 30 juin de chaque année, le Président désignera deux scrutateurs pour aider le Secrétaire administratif au dépouillement du scrutin. 
6.5.2.5.3 On or before July 31 of the same year, the Secretary-Manager shall announce the results of the election of all candidates whose names appeared on the ballot, to all Officers of the Institute and to all Chairmen and Secretaries of the Sections. $\mathrm{He}$ shall also announce the election results to all members at least thirty days before the next ensuing general meeting by a notice in an official publication of the Institute or by direct mail.

6.5.3 Replacement of First Vice-President. If the office of First Vice-President falls vacant without a successor having been elected, an election shall be instigated immediately. This election shall be conducted in accordance with the procedure described in By-law 6.5.2, except that the dates shall be modified as necessary.

6.5.4 Replacement of Second Vice-President. If the office of Second Vice-President falls vacant without a successor having been elected, the Board of Directors shall forthwith elect a Director to that office for the unexpired portion of the current term.

Term of Office

The term of office of the members of the Executive Committee shall be from the end of an Annual general meeting until the end of the next such meeting. However, a member elected to an office may assume that office immediately if it is vacant. Except as provided in By-law 5.3, he shall continue to hold office until his successor replaces him, as provided for in the By-laws, or until he resigns, whichever event shall occur first.

\subsection{Duties}

6.7.1 President. The President shall be the Chief Executive Officer of the Institute. He shall preside at all meetings of the Institute, of the Board of Directors and of the Executive Committee. He shall have the general and active management of the business of the Institute. He shall see that all orders and resolutions are properly dealt with.

6.7.2 First Vice-President. The First Vice-President shall, in the absence or disability of the President, perform the duties and exercise the powers of the President, and shall perform such other duties as the Board may impose upon him.

6.7.3 Second Vice-President. The Second Vice-President shall, in the absence or the disability of both the President and the First Vice-President perform the duties and exercise the powers of the President, and shall perform such other duties as the Board may impose upon him.

\subsection{Powers and Limitations}

The Executive Committee shall have such powers as may be conferred upon it by resolution of the Board of Directors and of general meetings, by letter ballot, and through these By-laws.

6.8.1 Powers from the Board of Directors. Power conferred upon the Executive Committee by the Board of Directors shall not exceed those of the Board itself and shall not conflict with the provisions of these By-laws. Powers thus conferred may be revoked or amended by resolution of the Board or of a general meeting.

6.8.2 Powers from general meetings. A general meeting may confer upon the Executive Committee any powers which do not conflict with these By-laws, and such powers may be revoked or amended only by another resolution of a general meeting.

6.8.3 Powers from letter ballot as per By-law 9.3.
Le ou avant le 31 juillet de la même année, le Secrétaire administratif fera part du résultat de l'élection à tous les candidats dont les noms apparaissaient au bulletin de vote, à tous les officiers de I'Institut et aux Présidents et Secrétaires de toutes les Sections. II devra aussi transmettre le résultat de l'élection à tous les membres au moins trente jours avant l'assemblée générale subséquente, par avis dans une publication officielle de l'Institut ou par courrier.

Substitution du premier Vice-Président. Si le poste de premier Vice-Président devient vacant avant qu'un successeur soit élu, une élection devra être préparée immédiatement. Cette élection sera conduite suivant la procédure décrite au règlement 6.5.2 sauf que les dates seront modifiées s'il y a lieu.

Substitution du second Vice-Président. Si le poste de second Vice-Président devient vacant sans qu'un successeur ait été élu, le Conseil d'administration élira aussitôt un administrateur à ce poste pour le reste du terme en cours.

\section{Terme d'Office}

Le terme d'office des membres du Comité exécutif s'étendra de la fin de l'assemblée générale annuelle jusqu'à la fin de l'assemblée suivante. Cependant, un membre élu à un poste pourra accéder à ce poste immédiatement s'il est vacant. Sauf comme prévu au règlement 5.3 , il continuera à l'occuper jusqu'à l'élection de son successeur, tel que prévu au présent règlement, ou jusqu'à ce qu'il résigne selon la première éventualité.

\section{Devoirs}

Le Président. Le Président sera l'administrateur en chef de I'Institut. II présidera toutes les assemblées de I'Institut, du Conseil d'administration et du Comité exécutif. II aura la direction générale et active des affaires de I'Institut. II verra à ce que toutes les directives et résolutions soient exécutées de la meilleure façon.

Le premier Vice-Président. Le premier Vice-Président devra, en l'absence ou l'incapacité du Président, accomplir les devoirs et exercer les pouvoirs du Président et accomplir toute autre tâche que le Conseil pourra lui imposer.

Second Vice-Président. Le second Vice-Président devra, en l'absence ou l'incapacité du Président et du premier VicePrésident, accomplir les devoirs et exercer les pouvoirs du Président et accomplir toute autre tâche que le Conseil pourra lui imposer.

Pouvoirs et Restrictions

Le Comité exécutif aura les pouvoirs qui lui seront attribués par résolutions du Conseil d'administration et des assemblées générales, par scrutin et d'après les présents règlements.

Pouvoirs par le Conseil d'administration. Les pouvoirs attribués au Comité exécutif par le Conseil d'administration ne doivent pas dépasser ceux du Conseil lui-même et ne doivent pas être en désaccord avec les termes de ces règlements. Les pouvoirs ainsi attribués peuvent être révoqués ou amendés par résolution du Conseil d'administration ou d'une assemblée générale.

Pouvoirs par résolution d'une assemblée générale. Le Comité exécutif peut recevoir lors d'une assemblée générale certains pouvoirs qui ne doivent pas être en désaccord avec ces règlements, tels pouvoirs pouvant être révoqués ou amendés seulement par une autre résolution d'une assem. blée générale.

Pouvoirs par scrutin. Voir le règlement 9.3. 


\subsubsection{Extraordinary circumstances.}

6.8.4.1 In exceptional circumstances and when the good of the Institute requires, the Executive Committee may exercise extraordinary powers, according to their collective competence and wisdom, and initiate action.

6.8.4.2 Such action must be communicated to the Board of Directors forthwith for consideration.

6.8.4.3 A two-thirds majority vote of the Board shall constitute approval.

6.8.4.4 These decisions must be made known to the members and upon the decision of the Board of Directors may be put to referendum or reported at a subsequent annual general meeting.

\section{$6.9 \quad$ Meetings}

6.9.1 Calling of meetings. The Executive Committee shall meet at the call of the President or the First VicePresident acting in the capacity of President.

6.9.2 Quorum. Either the President or the First VicePresident and one other of its members shall constitute a quorum of the Executive Committee.

\section{APPOINTED OFFICERS, AGENTS AND EMPLOYEES}

\subsection{Appointed Officers}

7.1.1 Definition. The appointed Officers shall be the Secretary-Manager and the Editor who need not be members of the Institute.

7.1.2 Appointment. The Secretary-Manager and the Editor shall be appointed by the Board of Directors. Each such appointment shall remain valid until revoked by the Board or by resolution of a general meeting or until the resignation of the incumbent.

7.1.3 Substitution. In the absence of or in the disability of any appointed Officer, the Executive Committee may appoint a temporary replacement.

\subsection{Duties of the Secretary-Manager}

\subsubsection{Financial.}

7.2.1.1 The Secretary-Manager shall have the custody of the Institute's funds and securities and shall keep full and accurate accounts of receipts and disbursements in books belonging to the Institute, and shall deposit all moneys and other valuable effects in the name and to the credit of the Institute and in such depositories as may be designated by the Board of Directors from time to time.

7.2.1.2 He shall disburse the funds of the Institute as may be ordered by the Board, taking proper vouchers for such disbursements, and shall render to the President and Directors at the regular meetings of the Board, or whenever they require it, an account of all his fiscal transactions on behalf of the Institute and of the financial position of the Institute.

7.2.1.3 He shall present to the Board before each annual general meeting a proposed final budget for the current financial year and a preliminary budget estimate for the ensuing financial year.

7.2.1.4 He shall give to the Institute a bond for the faithful performance of the duties of his office and for the restoration to the Institute in the event of his death, resignation, retirement or removal from office of all books, papers, vouchers, money and

\section{Circonstances extraordinaires.}

Dans les circonstances extraordinaires et pour le plus grand bien de I'Institut, le Comité exécutif peut exercer des pouvoirs extraordinaires d'après leur compétence et leur expérience indivisées et prendre une initiative.

Telle action doit être communiquée au Conseil d'administration sur-le-champ pour étude.

Une majorité des deux tiers des votes du Conseil constituera une approbation.

Ces actions devront être communiquées aux membres et sur décision du Conseil d'administration pourront faire l'objet d'un référendum ou d'un rapport à une assemblée générale annuelle subséquente.

\section{Réunions}

Avis de réunions. Le Comité exécutif se réunira à la demande du Président ou du premier Vice-Président agissant en temps que Président.

Quorum. Le Président ou le premier Vice-Président et un autre membre constitueront le quorum du Comité exécutif.

\section{ENGAGEMENT DES OFFICIERS, AGENTS ET EMPLOYÉS}

\section{Engagement d'Officiers}

Définition. Les officiers qui font l'objet d'un engagement sont le Secrétaire administratif et le Rédacteur en chef. Ces officiers ne doivent pas nécessairement être membres de I'Institut.

Engagement. Le Secrétaire administratif et le Rédacteur en chef sont engagés par le Conseil d'administration. Chaque nomination demeurera en force jusqu'au moment de sa révocation par le Conseil ou par une résolution de l'assemblée générale ou encore jusqu'à la résignation du titulaire.

Remplacement. Advenant que l'un des officiers précités devienne incapable de remplir sa fonction pour une raison ou pour une autre (absence, invalidité, etc.) le Comité exécutif pourra nommer un remplaçant temporaire.

\section{Responsabilités du Secrétaire Administratif}

\section{Finances}

Le Secrétaire administratif aura la garde des fonds et des valeurs de I'Institut. II devra garder dans les livres de I'Institut des notes précises et complètes des sommes perçues et dépensées et déposer tous les argents et autres valeurs au nom et au crédit de I'Institut chez les dépositaires désignés de temps à autre par le Conseil d'administration.

Il devra, selon des demandes formulées à ce sujet par le Conseil, débourser les argents de l'Institut et garder les pièces justificatives à cette fin. Lors des assemblées régulières du Conseil d'administration ou à la demande du Président et des administrateurs, il devra rendre compte à ces derniers de toutes les transactions financières exécutées au nom de I'Institut et aussi les tenir au courant de la situation financière de l'Institut.

II devra avant chaque assemblée générale annuelle présenter au Conseil le budget final proposé pour l'exercice financier en cours et aussi une estimation budgétaire préliminaire pour l'année suivante.

II devra fournir à I'Institut une police de garantie comme quoi il s'acquittera fidèlement des devoirs rattachés à sa fonction et advenant son décès, sa démission forcée ou volontaire ou sa mise à la retraite, tous les livres, papiers, pièces justificatives, argents ou les autres effets qui étaient entre ses mains ou sous son contrôle ou qui pourraient avoir disparu mystérieusement ou encore avoir été trans- 
other property of whatever kind in his possession or under his control, or which he may have improperly disposed of, or which may have mysteriously disappeared. Such bond shall be of such form, amount and surety as are acceptable to the Board.

Secretarial and general. The Secretary-Manager shall attend, and shall act as clerk of, all meetings of the Board of Directors at the pleasure of the Directors and of the Institute at the pleasure of the members. As clerk he shall record all votes and minutes of all proceedings in the books to be kept for that purpose. He shall give, or cause to be given, notice of all meetings of the members, and of the Board. Within thirty days of the election of each Officer and Director he shall supply them with copies of all resolutions then operative pertaining to the duties and responsibilities of the Executive Committee. He shall act as Secretary of the Executive Committee and shall perform such other duties as may be prescribed by the Board or the President, under whose supervision he shall be.

7.2.3 Custody of seal. The Secretary-Manager shall be the custodian of the seal of the Institute, which he shall deliver to another person or persons only as and when authorized by the Executive Committee.

\subsection{Agent and Employees}

The Executive Committee may appoint agents and engage employees who shall have such authority and duties as the Committee prescribes.

\subsection{Remuneration}

The remuneration of appointed Officers, agents and employees shall be fixed by resolution of the Executive Committee subject to endorsement by the Board of Directors.

The financial year of the Institute shall be the period from the first day of July to the thirtieth day of June next.

\section{Meeting Arrangements}

Calling of meetings. The Board of Directors shal determine the time and place of any annual or special general meeting of the Institute, and thirty days written notice shall be given to all classes of members.

9.1.2 Annual general meeting. The annual general meeting of the Institute shall be held not less than two and not more than six months after the last day of the financial year, except that under exceptional circumstances these deadlines may be waived at the direction of the Board of Directors.

9.1.3 Special meetings. A special general meeting may be called, upon a formal request by a Section Council acting on a Resolution approved at a duly constituted general meeting of the Section, or following a written request endorsed by thirty-five voting members of the Institute.

\section{$9.2 \quad$ Quorum and Voting}

9.2.1 Quorum. Thirty-five voting members present in person at a general meeting shall constitute a quorum.

9.2.2 Voting rights. Only Active members may vote in the affairs of the Institute. Each Active member present at a general meeting shall have the right to exercise one vote except that an Active member may appoint, in writing, any other Active member present at the meeting to vote as his proxy. férés malhonnêtement à d'autres personnes ou organisations, devront être retournés à l'Institut. La nature et le montant de la police de garantie exigée du Secrétaire administratif seront sujets à l'approbation du Conseil d'administration.

Secrétariat et généralités. Le Secrétaire administratif devra assister à toutes les réunions du Conseil d'administration au bon plaisir des administrateurs ainsi qu'aux assemblées de I'Institut au bon plaisir des membres. II agira alors comme secrétaire. II devra, dans les livres gardés à cette fin, consigner tous les votes pris et résumer les délibérations. II devra donner ou faire donner les avis requis pour annoncer la tenue d'assemblées par les membres ou par le Conseil d'administration. Durant les trente jours suivant l'élection de chaque officier ou de chaque administrateur, il devra fournir à ces derniers des copies de toutes les résolutions alors en force se rapportant aux devoirs et responsabilités du Comité exécutif. II devra agir comme secrétaire du Comité exécutif et s'acquitter en plus de toutes les autres fonctions qui pourraient lui être indiquées par le Conseil d'administration ou par le Président. qui sont responsables pour la surveillance de son travail.

Garde du sceau. Le Secrétaire administratif aura la garde du sceau de I'Institut. II pourra remettre le sceau à une autre personne ou à d'autres personnes seulement lorsqu'il sera autorisé à le faire par le Comité exécutif.

\section{Agents et Employés}

Le Comité exécutif pourra nommer des agents et engager des employés dont l'autorité et les fonctions seront définies par ledit comité.

\section{Rémunération}

La rémunération des officiers, agents ou employés nommés ou engagés sera fixée par résolution du Comité exécutif, sujet à l'approbation du Conseil d'administration.

\section{EXERCICE FINANCIER}

L'exercice financier de l'Institut comptera du premier jour de juillet au trentième jour de juin suivant.

\section{ASSEMBLÉES ET VOTES}

\section{Modalités des Assemblées}

Convocation des assemblées. Le Conseil d'administration déterminera la date et l'endroit de toute assemblée générale annuelle ou extraordinaire de I'Institut, et un avis écrit de trente jours devra être envoyé aux membres de toutes. catégories.

Assemblée générale annuelle. L'assemblée générale annuelle de I'Institut devra être tenue pas moins de deux mois et pas plus de six mois après le dernier jour de l'exercice financier, mais dans des circonstances exceptionnelles, le Conseil d'administration peut changer ces limites de temps.

Assemblées extraordinaires. Une assemblée générale extraordinaire peut être convoquée sur demande expresse du Conseil d'une Section donnant suite à une résolution approuvée par l'assemblée générale en bonne et due forme de la Section, ou à la suite d'une demande écrite endossée par trente-cinq votants de l'Institut.

\section{Quorum et Vote}

Quorum. Trente-cinq membres votants présents en personne à une assemblée générale constitueront le quorum.

Droits de vote. Seuls les membres actifs peuvent voter sur les questions d'affaires de l'Institut. Tout membre actif présent à une assemblée générale aura le droit d'exercer un vote mais un membre actif peut déléguer, par écrit. un autre membre actif présent à l'assemblée, son fondé de pouvoir. 
Voting and majority decision. At all meetings of the members of the Institute every question shall be determined by a majority of votes unless otherwise specifically provided by the Corporations Act, or by these By-laws. Voting shall be by a show of hands or a ballot as required by the Board of Directors or the Chairman of the meeting, except as described in By-law 9.3.

\subsection{Letter Ballot}

9.3.1 Authorization. The Board of Directors may direct the preparation, circulation and scrutiny of a letter ballot to obtain the wishes of the voting members upon a choice of policy or a line of action except in cases where:

a/ Amendment of By-laws is in question or

b/ The Canada Corporations Act prescribes the holding of a meeting of members.

Any such letter ballot shall state whether the results are intended to be binding primarily upon the membership as a whole, or- on the Board of Directors in the performance of its duties.

9.3.2 Communication and application of resolutions. The Secretary-Manager shall communicate the results to the membership without undue delay through the Section Chairmen and the Directors and through a notice in the next issue of an official publication whereupon these results shall be binding upon the parties concerned.

\section{Procedure}

In all cases not otherwise provided for in the By-laws, the most recent edition of Beauchesne's "Rules and Forms of the House of Commons of Canada" shall govern the proceedings of all meetings of the Institute.

\section{AUDITORS}

At each annual general meeting the Board of Directors shall recommend for appointment by the Active members an Auditor, or Auditors, to audit the accounts of the Institute and to hold office until the next annual general meeting, except that any unforeseen vacancy in the office of Auditor may be filled by appointment of the Executive Committee. The remuneration of the Auditor, or Auditors, shall be fixed by the Executive Committee within the budget of the Institute.

\section{SIGNING AND CERTIFYING OF DOCUMENTS}

\section{Signing Officers}

Contracts, documents, or any instruments in writing requiring the signature of the Institute shall be signed by any two of the President, First VicePresident, Second Vice-President, or SecretaryManager, and shall then be binding upon the Institute without further authorization or formality.

\subsection{Special Appointment of Signing Officers}

The Board of Directors may, as necessary, appoint by resolution an Officer, or Officers to sign specific contracts, documents and instruments in writing on behalf of the Institute; the seal of the Institute may be fixed to such signed articles when required.

\section{Composition and Appointment}

The Board of Examiners shall consist of three members appointed by the Executive Committee for a term of three years in such a manner that one member retires and is replaced at the end
Vote et décision majoritaire. A toute assemblée de membres de l'Institut, toute décision sera déterminée par la majorité des votes à moins qu'il en soit spécifié autrement dans la Loi sur les corporations canadiennes, ou dans les présents règlements. Le vote peut se faire à main levée ou par scrutin tel que requis par le Conseil d'administration ou le Président de l'assemblée, excepté tel que décrit au règlement 9.3 .

\section{Scrutin par la Poste}

Autorisation. Le Conseil d'administration peut ordonner la préparation, l'expédition et le dépouillement d'un scrutin par la poste afin de recueillir l'opinion des membres votants sur une question de politique ou sur une ligne de conduite à prendre sauf dans les cas suivants:

a/ Un amendement aux règlements;

b/ lorsque la Loi sur les corporations canadiennes exige la tenue d'une assemblée des membres.

Un tel scrutin par la poste devra spécifier si les résultats engageront principalement tous les membres, ou le Conseil d'administration dans l'accomplissement de ses devoirs.

Communication et mise à exécution des résolutions. Le Secrétaire administratif communiquera sans délai les résultats aux membres par l'entremise des Présidents de Section et des administrateurs, et par un avis dans le prochain numéro d'une publication officielle après quoi les résultats engageront les parties en cause.

\section{Procédure}

Dans tous les cas non prévus aux règlements, la plus récente édition du "Précis de procédure parlementaire à la Chambre des Communes du Canada" par Beauchesne, régira les débats de toutes les réunions de l'Institut.

\section{VÉRIFICATEURS}

Lors de l'assemblée générale annuelle, le Conseil d'administration devra proposer, à l'assentiment des membres actifs, un ou des vérificateurs pour examiner les livres de I'Institut avec mandat effectif jusqu'à l'assemblée générale annuelle subséquente sauf qu'une vacance imprévisible au bureau du vérificateur peut être comblée par la nomination d'un remplaçant par le Comité exécutif. La rémunération du ou des vérificateurs sera fixée par le Comité exécutif à même le budget de l'Institut.

\section{SIGNATURE ET ATTESTATION DES DOCUMENTS}

\section{Signataires}

Les contrats, documents ou tout autre écrit nécessitant la signature de l'Institut doivent être signés par deux des personnes suivantes: Le Président, le premier Vice-Président, le second Vice-Président ou le Secrétaire administratif et alors lieront I'Institut sans autre autorisation ou formalité.

\section{Nomination Spéciale de Signataires}

Le Conseil d'administration peut, en cas de nécessité, désigner par résolution un ou des administrateurs pour signer au nom de l'Institut des contrats, documents et écrits spécifiques; le sceau de I'Institut peut être apposé à ces signatures lorsque requis.

\section{BUREAU DES EXAMINATEURS}

\section{Composition et Nomination}

Le Bureau des Examinateurs sera composé de trois membres désignés par le Comité exécutif pour un terme de trois ans de telle manière qu'un membre se retire et soit remplacé à la fin de chaque assemblée générale annuelle. 
of each annual general meeting. If a member does not complete his term of office a replacement may be appointed for the remainder of that term.

12.1.2 The appointed member who has served two years on the Board of Examiners shall normally become Chairman in his third year. Failing this, appointment to such office shall be made by the Executive Committee.

12.1.3 The Secretary-Manager shall be a member, ex officio, of the Board.

\subsection{Duties}

The duties of the Board of Examiners shall be to examine the qualification of those applying for membership in the Institute as and when prescribed in By-law 3, and also to examine the qualifications of any applicant in case of uncertainty.

\section{Establishment}

13.1.1 Application by members. The basis of forming a new Section shall be an application by at least twenty voting members made to the Board of Directors requesting the formation of a Section in the area in which they work and reside.

13.1.2 Establishment by directors. The Board of Directors may, by resolution, establish Sections in such areas and with such functions, regulations and limitations as they see fit.

\subsection{Membership}

The qualification for membership in a Section shall be membership in the Institute.

\subsection{Section Council}

13.3.1 Composition and duties. The affairs of a Section shall be managed by a Council consisting of a Chairman, a Vice-Chairman, a Secretary-Treasurer, the Section Representative on the Board of Directors, and not less than two nor more than five additional members. The Chairman and the ViceChairman of the Section and the Section Representative on the Board of Directors shall be Active members of the Institute. It shall be the responsibility of the Chairman and the Secretary-Treasurer to maintain contact with the Officers of the Institute.

13.3.2 Appointment. The members of the Council shall be members of the Section and shall, with the exception of the Secretary-Treasurer, be elected by ballot of the members of the Section. They shall be elected each year, or every other year, according to the regulations adopted by the Section, and shall hold office until the end of the fiscal year of the Section, or until such date as their successors have been declared elected. The Section Representative on the Board of Directors and his Alternate shall be elected as provided by By-law 5.2.

The Secretary-Treasurer shall be appointed by the Section Council each year and shall hold office until his successor has been appointed.

13.3.3 Meeting and quorum. Meetings of a Section Council may be held at any time and place as determined by the members of the Council, provided that four days notice of such meeting shall be sent in writing to each Council member. Half of the members of the Council shall constitute a quorum.
Si un membre ne peut compléter son mandat, un remplaçant peut être désigné pour le reste du terme.

Le membre qui a siégé depuis deux ans au Bureau des Examinateurs en sera normalement le Président à sa troisième année. A défaut, le Comité exécutif devra nommer un autre membre.

Le Secrétaire administratif sera membre d'office de ce Comité.

\section{Fonctions}

Les fonctions du Bureau des Examinateurs seront d'examiner les titres des personnes désirant devenir membres de I'Institut selon les prescriptions de l'article 3 , et aussi d'examiner les titres de tout candidat où il $\mathrm{y}$ a incertitude.

\section{SECTIONS}

\section{Fondation}

Requête par les membres. La demande initiale en vue d'obtenir la formation d'une nouvelle Section doit consister en une requête signée par au moins vingt membres en règle, faite au Conseil d'administration demandant la fondation d'une Section dans le territoire de leurs lieux de travail et de résidence.

Fondation par les administrateurs. Le Conseil d'administration peut, par résolution, fonder des Sections à certains endroits pour des fins précises et en déterminer les règlements et les restrictions qu'il juge à propos.

\section{Membre}

II faut être membre de l'Institut pour devenir membre d'une Section.

\section{Conseil de la Section}

Composition et devoirs. Les affaires de la Section doivent être administrées par un Conseil se composant d'un Président, d'un Vice-Président, d'un Secrétaire-trésorier, d'un Représentant de la Section au Conseil d'administration et de deux à cinq membres additionnels. Le Président, le Vice-Président de la Section et le Représentant de la Section au Conseil d'administration doivent être des Membres Actifs de I'Institut. Le Président et le Secrétaire-trésorier sont responsables du maintien des relations avec les officiers de I'Institut.

Nominations. Les membres du Conseil doivent être membres de la Section et doivent, à l'exception du Secrétairetrésorier être élus au scrutin par les membres de la Section. Ils doivent être élus chaque année ou à tous les deux ans, selon les règlements adoptés par la Section, et ils doivent demeurer en fonction jusqu'à la fin de l'année fiscale de la Section ou jusqu'au moment où leurs successeurs ont été déclarés élus. Le Représentant de la Section au Conseil d'administration et son substitut doivent être élus tel que prévu au règlement $\mathbf{5 . 2}$.

Le Secrétaire-trésorier doit être désigné chaque année par le Conseil de la Section et doit demeurer en fonction jusqu'à la nomination de son successeur.

Réunion et quorum. Les réunions du Conseil de la Section peuvent être tenues au lieu et au temps fixés par les membres du Conseil en autant qu'un avis de la tenue d'une telle réunion a été envoyé par écrit à chacun des membres du Conseil quatre jours à l'avance. La moitié des membres du Conseil formeront le quorum. 
A Section shall hold an annual meeting, preferably in the spring, at which the members shall receive a report of the Council.

Dues

A Section may collect from its members, for its own use, such dues as are determined at a general meeting of the Section.

13.6 Commitment of the Institute

A Section may not commit the Institute by its actions.

13.7 Rules and Regulations

A Section may adopt such rules and regulations for its own government as are not inconsistent with these By-laws.

\section{RULES AND REGULATIONS}

The Board of Directors may make, amend or cancel such rules and regulations as they deem fit for the proper management and operation of the Institute. Such changes of the rules and regulations must not be inconsistent with these By-laws, and shall have effect until the next annual general meeting of the Institute when they shall be ratified, repealed or amended by the membership. If ratified, with or without amendments, they shall have effect until further amended or repealed as herein described.

\section{Amendment}

15.1.1 The Board of Directors may from time to time make, repeal, amend or re-enact By-laws. Such changes must be confirmed at a general meeting, duly called for that purpose, by an affirmative vote of at least two-thirds of the Active members voting at that meeting.

15.1.2 Changes of the By-laws shall not take effect until approval of the Corporations Branch, Department of Consumer and Corporate Affairs has been obtained.

\section{Assemblée Annuelle}

Une Section doit tenir une assemblée annuelle de préférence au printemps, alors qu'un rapport du Conseil sera présenté aux membres.

\section{Cotisation}

Une Section peut percevoir de ses membres, pour ses propres besoins, une cotisation telle qu'établie à une assemblée générale de la Section.

Engagement de I'Institut

Une Section ne peut pas engager l'Institut par ses actions.

\section{Réglementation}

Une Section peut adopter des règlements et règles de pratique pour sa propre gouverne en autant qu'ils ne sont pas en contradiction avec les règlements de l'Institut.

\section{RÈGLES DE PRATIQUE}

Le Conseil d'administration peut faire, amender ou révoquer, toute règle de pratique s'il le juge à propos pour l'administration et la conduite efficace des affaires de l'Institut. De telles règles ne doivent pas être en contradiction avec les règlements généraux et demeurent en vigueur jusqu'à l'assemblée générale annuelle subséquente de I'Institut alors qu'elles seront ratifiées, rejetées ou amendées par les membres. Si ratifiées, avec ou sans amendements, elles seront en vigueur jusqu'à ce qu'elles soient à nouveau amendées ou révoquées selon la procédure décrite ici.

\section{RÈGLEMENTS}

\section{Amendement}

Le Conseil d'Administration peut en tout temps faire, révoquer, amender ou remettre en vigueur certains règlements. De tels changements doivent être approuvés à une assemblée générale, dûment convoquée à cette fin, par au moins les deux tiers des membres actifs votant à cette réunion.

Les changements aux règlements généraux ne peuvent prendre effet qu'après avoir été approuvés par le Bureau des Corporations du Ministère de la Consommation et des Corporations. 


\section{MAINTENANT}

\section{jusqu'à $\$ 100,000$ d'assurance-vie à prix modique en vertu du plan de l'Institut Forestier du Canada}

Des changements importants ont récemment été faits au plan d'assurance-vie de I'Institut Forestier.

L'assurance peut être obtenue en unités de $\$ 10,000$, pour ceux dont l'âge est de jusqu'à 50 ans, inclusivement, et vous pouvez faire demande de jusqu'à 10 unités. Le montant des unités décroît pour les membres plus âgés.

Exemple - pour un membre jusqu'à l'âge de 30 ans, le coût n'est que de $\$ 20.00$ par unité de $\$ 10,000$. Ce qui signifie $\$ 200$ par année, pour $\$ 100,000$ d'assurance-vie.

Pour âge de 31 à 40 ans, le coût n'est que de $\$ 28.00$ par unité de $\$ 10,000$.

Des détails complets sont donnés au nouveau dépliant maintenant en voie de préparation, et qui pourra être obtenu du bureau de l'Institut Forestier, Casier postal 5000, Collège Macdonald, P.Q.

BONI SPÉCIAL - Vu l'expérience favorable de mortalité, un boni de $50 \%$ sera payable en cas de décès durant la période du 1er mai 1976 au 30 avril 1977.

Le boni de $25 \%$ institué il y a 11 ans, a maintenant été augmenté à $50 \%$. Ce qui signifie que pour $\$ 100,000$ d'assurance, $\$ 150,000$ seront payables en cas de décès, durant ladite période de 12 mois, et ceci, sans changer le coût.

Vous pouvez aussi obtenir, en vertu du plan, de l'assurance-vie à prix modique, pour votre époux/épouse.

L'Impériale a augmenté le montant payable en vertu du plan de l'Institut Forestier, à cause de l'augmentation de vos besoins d'assurance, en marge de la situation économique actuelle.

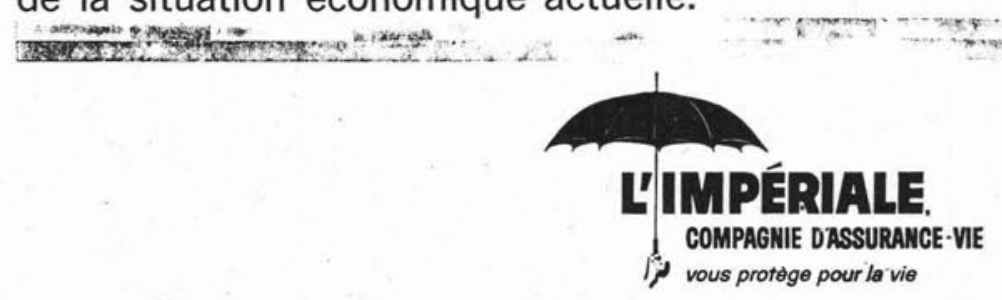

